\title{
Detection of Escherichia Coli in Freshly Harvested Spinach Samples Collected from Five Different Markets in Zaria
}

\author{
Karaye GP${ }^{1 *}$, Karaye $\mathrm{KK}^{2}$ and Kaze $\mathrm{PD}^{1}$ \\ ${ }^{1}$ Department of Veterinary Parasitology and Entomology, University of Jos, Nigeria \\ ${ }^{2}$ National Veterinary Research Institute, Nigeria \\ *Corresponding author: Karaye GP, Department of Veterinary Parasitology and Entomology, University of Jos, Nigeria. \\ To Cite This Article: Karaye GP. Detection of Escherichia Coli in Freshly Harvested Spinach Samples Collected from Five Different Markets in \\ Zaria. Am J Biomed Sci \& Res. 2019 - 4(2). AJBSR.MS.ID.000777. DOI: 10.34297/AJBSR.2019.04.000777
}

Received: June 29, 2019 | Published: July 23, 2019

\begin{abstract}
Escherichia coli, though, normal flora of the digestive tract of human and animals have over the years evolved the ability to cause a wide range of disease. A total of 100 freshly harvested and ready to sale spinach samples in five selected market in Zaria, Kaduna State were collected and analysed for E.coli 0157: H7. Twenty (20) samples each were collected from Sabon Gari, Palladan, Samaru, Hayin Dogo and PZ. Isolates were screened using the conventional biochemical characterization for E. coli 0157: H7. Twelve (12) gram of spinach leaves each was washed with sterile distilled water. Five (5) mls of each washing was inoculated into $5 \mathrm{mls}$ of double strength Mac Conkey broth and inoculated for 24 hours at $37^{\circ} \mathrm{C}$. A loop full of the positive colonies was subcultured on EMB Agar and incubated for $24 \mathrm{~h}$ at $37^{\circ} \mathrm{C}$ a greenish metallic sheen on the surrounding medium were observed. These presumptive positive colonies were stored in nutrient Agar slant at $4^{\circ} \mathrm{C}$ until it was required for biochemical test. E. coli was confirmed by biochemical test and the growth on EMB Agar. Out of the 100 samples collected, Isolates were screened using the conventional biochemical characterization for E. coli 0157: H7. A total of 119 (47.6\%) E. coli 0157: $\mathrm{H} 7$ and 16 (6.4\%) E. coli 0157 was isolated respectively. Therefore, there is need to characterize the E. coli from spinach in local markets in Zaria, so as to checkmate and create awareness on the spread of E. coli especially 0157:H7 infection in livestock and humans in Zaria and Kaduna State. .
\end{abstract}

Keywords: Escherichia coli; Spinach; Zaria; Biochemical test; EMB Agar; Vokes Proskaur

\section{Introduction}

Escherichia coli are natural predominant facultative anaerobes common in the lower intestines of endothermic animals and it grows in most laboratory media at an incubation temperature of $\left(37^{\circ} \mathrm{C}\right)$ optimum [1]. They colonize the gastrointestinal tract hours after birth or days after [2]. Nevertheless, some strains have evolved the capability to cause both intestinal and extra intestinal illnesses $[3,4]$. Not all the strains are harmless, as some can cause debilitating and sometimes fatal diseases in humans as well as mammals and birds [5]. Faecal-oral transmission is the major route through which pathogenic strains of the bacterium cause disease. Cells of the bacteria can survive outside the body for a limited amount of time, which makes them potential indicator organisms to test environmental samples for faecal contamination [6,7]. In Zaria, Tijani et al. [8], Kabiru et al. [9] reported the prevalence of Escherichia coli 0157:H7 in spinach grown around abattoir waste dumpsite, manure farm and soil, irrigated with raw abattoir wastewater. This suggests that spinach are vegetables that can potentially harbor
Escherichia coli when manured with contaminated faeces. The use of raw manure or slurry (liquid manure) on or near fruit and vegetable crops, particularly those to be eaten raw is a potential hazard for Escherichia coli especially 0157:H7 [8] and hence the need for work to be done on the prevalence of E.coli in spinach meant for human consumption in Zaria and its environs. Studies have shown that Escherichia coli especially 0157:H7 can survive in faeces for extensive periods of 70-100 days at the temperature in the region of $45{ }^{\circ} \mathrm{C}[10]$. Thereby establishing that faeces serving as manure to most subsistence and commercial farmers growing spinach at backyard or irrigational farms at dry season may be a potential vehicle for transmission of the organism into the environment [11].

\section{Materials and Methods}

\section{Study Area}

The study was carried out in Samaru Campus of ABU, Zaria, Sabon Gari Local Government Area of Kaduna State. Located on 
Latitude $\left(11^{\circ} 11^{\prime} \mathrm{N}, 07,38^{\prime} \mathrm{E}, 686 \mathrm{~m}\right.$ above sea level) in the Northern Guinea Savannah with temperature ranging from $13.8^{\circ}$ to 36.7 ${ }^{\circ} \mathrm{C}$. Annual rainfall of $1092.8 \mathrm{~mm}$ [12]. Farming system in Zaria can be divided into two types: Rainfall (from May to October) and irrigation farming in the dry season (from November to April). Dry season farming is the second most prevalent Agricultural activity in Zaria with vegetables being the common produce, but in some cases, fruits are sandwiched among cereal crops [13].

\section{Sample Collection}

A total of 100 samples of freshly harvested spinach leaves were procured randomly in sterile polythene bags from 5 different open markets in Zaria metropolis. Twenty (20) samples each were collected from Sabon Gari, Samaru, Hayin-Dogo, Palladan and PZ markets and transported on ice cold packs of the laboratory and analyzed immediately.

\section{Isolation and Identification}

Freshly plucked spinach samples were purchased from five different markets in Zaria Metropolis, the stem and roots were removed and discarded, while the leaves were washed thoroughly with distilled water and the washing was placed in universal bottles. Five mls of the spinach washing was inoculated into $5 \mathrm{mls}$ of double strength Mac Conkey broth and inoculated for 24 hours at $37{ }^{\circ} \mathrm{C}$. A loop full of the positive colonies was subcultured on EMB Agar and incubated for $24 \mathrm{~h}$ at $37^{\circ} \mathrm{C}$ a greenish metallic sheen on the surrounding medium were observed. Pure culture of all colonies on EMB agar that exhibited typical dark purple red colour with metallic sheen which characterized E. coli were again subculture on Mac Conkey agar for identification and purification of lactose fermenting colonies. Biochemical tests such as indole, citrate, carbohydrate fermentation tests and MR-VP test were done on all lactose fermenting colonies to confirm E. coli. All the Lactose fermenting colonies were picked and stored in nutrient Agar slants (Oxoid) at 4 ${ }^{0} \mathrm{C}$ for further test. Biochemical test that were carried out to isolate E. coli, includes: Triple Sugar ion (TSI), Indole, Urease, Citrate, Motility, Methyl Red (MR), Vokes Proskaur (VP) and $\mathrm{H}_{2} \mathrm{~S}$ production.

\section{Biochemical tests}

The conventional biochemical test was conducted according to [14]. Five different biochemical media were used, and all media were prepared according to manufacturer's instructions.

\section{Citrate utilization test}

This test is based on the ability of an organism to use citrate as its source of carbon. A sterile wire loop was used to inoculate the isolate onto the Simon's citrate agar medium, which was already prepared as slant in test tubes, and incubated at $37^{\circ} \mathrm{C}$ for 24 hours after which it was examined for color change. A bright blue color in the medium was observed at against green coloration.

\section{Methyl red voges proskauer test (MRVP)}

A loop full of the organism was inoculated into a MRVP media and incubated at $37^{\circ} \mathrm{C}$ for 24 hours. The turbid positive broth was divided into two halves, 2-3 drops of methyl red was added to one broth and observed for formation of pink color coloration, while to the remaining half, 5 drops of $40.0 \%$ potassium hydroxide $(\mathrm{KOH})$ and 5 drops of $5.0 \%$ of alcoholic alpha- 45 Naphthol were added and shaken vigorously for homogenization. The cap of the tube is placed in a sloping position. The development of a red color starting from the liquid air interface within 15-30minutes was indicative of a positive test.

\section{Urease test}

Urease hydrolyzes urea to give alkaline ammonia $\left(\mathrm{NH}_{4}\right)$ and carbon dioxide. Urease liquid media was poured in three to five milliliters portion in a sterile screw-top glass tube. The tubes were inoculated with a loop full of the positive isolate using a sterile wire loop, but the tubes were placed in a slanting position and incubated at $37{ }^{\circ} \mathrm{C}$ for 24 hours. A pink color indicating positive test while a yellow colouration was considered negative.

\section{Indole test}

A sterile wire loop was used to inoculate a colony of the positive organism into a prepared SIM (Sulphide, Indole and Motility) media. The tube was capped and incubated at $37{ }^{\circ} \mathrm{C}$ for 24 hours. After incubation, four drops of Kovac's reagent was added to the medium using a sterile pasteur pipette to examine for the production of indole by the organism. Observation of red coloration on the surface layer within ten minutes gave a positive result. The suspected isolates when inoculated into the medium using a sterile straight wire followed by incubation by $37^{\circ} \mathrm{C}$ for 24 hours. The upper layer of the inoculated medium and line of stabbing was observed for the presence of dark coloration which will be indicative of a positive $\mathrm{H}_{2} \mathrm{~S}$ test.

\section{Motility test}

Motility test medium was poured into test tubes and allowed to solidify. The tubes were inoculated with a colony of the test organism using a sterile wire pin and incubated at $37^{\circ} \mathrm{C}$ for twenty-four hours before tests were read.

\section{Triple sugar iron agar}

Carbohydrates fermentation test in triple sugar iron agar slants were performed from commercially prepared TSI mix and poured in to a test tube which is placed in such a manner to allow the butt of the agar to be four centimeters deep, the slants were inoculated with a colony of the test organism using a sterile wire loop. Observable color changes as red and pink were interpreted as alkaline and acids with or without gas formation.

\section{Results}

Tables $1 \& 2$ shows the frequency and distribution of suspected E. coli isolated from spinach gotten from five different sites in Zaria Metropolis, Kaduna State. Using EMB, while Table 2, further confirms the presence of the E. coli, using the conventional Biochemical Test method. Out of the 100 samples of spinach screened for E. coli 119 (47.6) \% were positive with typical growth on EMB as shown in Table 1 . The results showed that Hayin Dogo had the least number of E. coli positive isolates on EMB 14 (28.0\%). In addition, Palladan 
had the highest positive isolates on EMB 28 (56\%). Further screening of the isolate with conventional biochemical tests showed a de- crease in total number and percentages of confirmed $E$. coli isolate on both EMB agar from 119 (47.6) and 16(6.4) respectively.

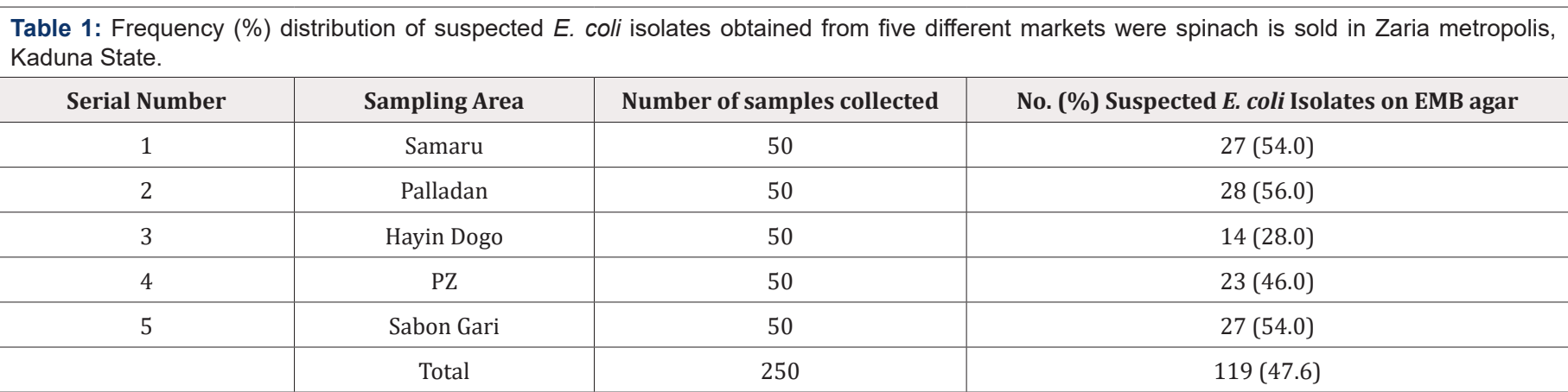

Key: EMB: Eosin Methylene Blue

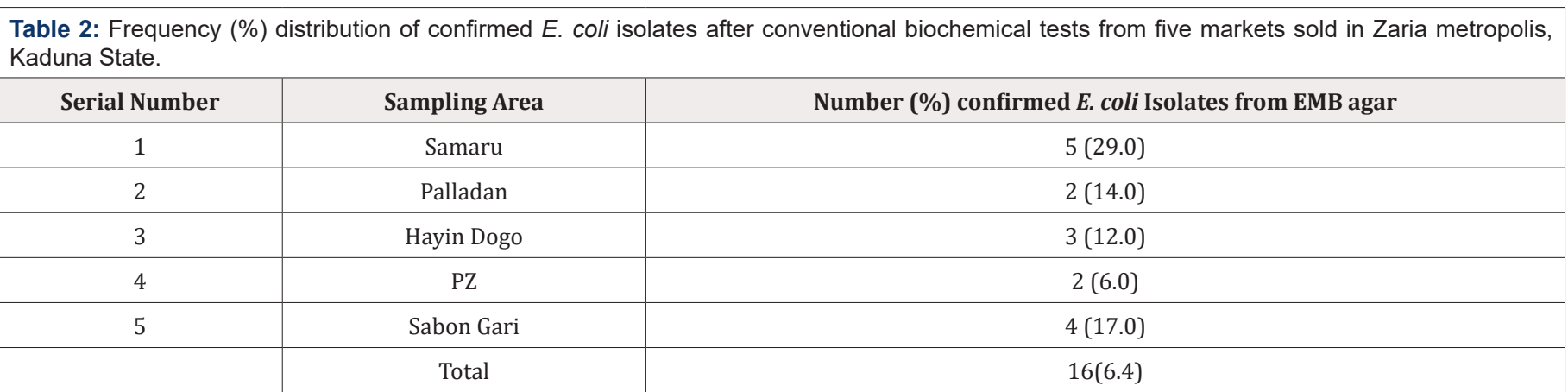

Key: EMB: Eosin Methylene Blue

\section{Discussion}

The result from this research showed that Escherichia coli 0157: H7 were cultured from spinach sourced from five different open markets in Zaria metropolis, Kaduna State. An occurrence of 119 (47.6\%) E. coli 0157: H7 and 16 (6.4\%) E. coli 0157: H7 respectively was observed which is higher than the occurrence reported by Reuben \& Makut [15], Enabulele \& Uraih [16] with a prevalence rate of $17.5 \%$ and $19.5 \%$ in Lafia and Benin Metropolises respectively. In other parts of the World, Mora et al. [17] and Benard [18] reported occurrence rates of $18.2 \%$ and $21.66 \%$ respectively. The high occurrence of E.coli as observed in this research could be attributed to high microbial load on vegetables especially those grown around faecal waste dumpsite during e dry season when there is no rainstorm-washing to reduce the microbial load on the vegetables as reported by [19]. Solomon et al. [20] and Kabiru et al. [9] also opined that manure application and irrigation with contaminated water as frequently done during the dry season in Zaria metropolis could have been another reason for this finding in which isolates were confirmed highly E. coli positive. This also agrees with earlier isolation records by Brown et al. [21] who reported that E. coli especially 0157:H7 is more common in warmer months of the year and sampling plans that could include these times of the year, will result in higher recovery rates. The isolation of the pathogen (E. coli 0157: H7) in Zaria metropolis suggests that contamination of spinach sold to consumers exposes them to food-borne hazards. The socio-economic implication is that resources and time are wasted on medication. The effects of food-borne infections are also greatly felt by immune-compromised individuals such as people living with HIV/AIDS, pregnant women, children, diabetic patients [22].
Leafy vegetables are an essential component of a healthy diet; however, they have been associated with high-profile outbreaks causing severe illnesses $[23,24]$. In addition to E. coli capacity to cause infection to humans, the ingestion of contaminated foods, water and vegetables offered to livestock may contribute to the prevalence of infections in farm animals with a resultant contamination of the environment [25-29].

\section{Conclusion}

The findings of this research have indicated the occurrence of Escherichia coli 0157:H7 in spinach sourced from five open markets in Zaria Metropolis. This portends public health consequences to the unsuspecting general populace who would usually ingest such vegetable. There is therefore the need to educate the public on personal and environmental hygiene and adherence to good food handling practices such as washing of hands and disinfecting of all vegetables thoroughly before consumption. It is also the authors' opinion that further research work be conducted to characterize at molecular level, the E. coli from spinach in local markets in Zaria.

\section{References}

1. Feng PHC, Jenneman K, Scheutz F, Monday SR (2011) Specificity of PCR and Serological Assays in the detection of Escherichia coli Shiga Toxin subtypes. Applied environmental microbiology 77(18): 6699-6702.

2. Lan R, Reeves PR (2002) Escherichia coli in disguise: molecular origins of Shigella. Microbes Infect 4(11): 1125-1132.

3. Nataro JP, Bopp CA, Fields PI, Kaper JB, Strockbine NA, et al., (2011) In Manual of Clinical Microbiology. Versalovic, J, Carroll KC, Funke G, Jorgensen JH, Landry ML, et al., (Eds). ASM Press, Washington, DC, USA, pp. 603-626. 2. 
4. Quinn PJ, Markey BK, Leonard FC, Fitz Patrick ES, Fanning S, et al., (2011) Enterobacteriaceae. In Veterinary Microbiology and Microbial Diseases, $2^{\text {nd }}$ edn. Wiley \& Blackwell, Hoboken, NJ, USA, pp. 263-286.

5. Belanger L, Garenaux A, Harel J, Boulianne M, Nadeau E, et al. (2012) Escherichia coli from animal reservoirs as potential source of human extra intestinal pathogenic E. coli. FEMS Immunology and Medical Microbiology 62(1): 1-10.

6. Feng P, Weagant S, Grant M (2002) Enumeration of Escherichia coli and the Coliform Bacteria. Bacteriological Analytical Manual $8^{\text {th }}$ edition. FDA/Center for Food Safety and Applied Nutrition.

7. Thompson, Andrea (2007) E. coli Thrives in Beach Sands. Live Science. 3(2): 21-28.

8. Tijani MB, Umoh VJ, Jatau ED (2006) Occurrence of pathogens on vegetables grown around abattoir waste dumpsite, manured farm and soil, irrigated with raw abattoir wastewater. Ahmadu Bello University Zaria, Nigeria.

9. Kabiru LM, Bello M, Kabir J, Grande L, Morabito S (2015) Detection of pathogenic E. coli in samples collected at an abattoir in Zaria, Nigeria and at different points in the surrounding environment, International journal of environmental research in public health 12(1): 679-691.

10. Dahiru M, Uriaih N, Enabulele SA, Shamsudeen U (2008) Prevalence of Escherichia coli 0157: H7 in fresh and roasted beef in Kano city of Nigeria. Journal of pure and Applied Sciences 1(1): 39-42.

11. Wang Y, Huang SH, Wass C, Kim KS, Stins MF (1999) The gene locus yiJp contributes to E. coli K1 invasion of brain microvascular endothelial cells. Infect Immun 67(9): 4751-4756.

12. Aliyu YA, Musa IJ, Youngu TT (2013) Appraisal of sulphur contamination from Transportation in Urban Zaria, Nigeria. International Letters of Natural Science 2: 19-30.

13. Agbogu VN, Umoh VJ, Okuofu CA, Smith SI, Ameh JB (2006) Study of the bacteriological and physicochemical indicators of the pollution of surface waters in Zaria, Nigeria. African Journal of Biotechnology 5(9): 732-737.

14. Barrow GI, feltham RK (1993) Cowan and Steel, Manual for identification of Medical bacteria. $3^{\text {rd }}$ Edition. Cambrige University Press, UK, pp. 199241.

15. Reuben CR, Makut MD (2014) Occurrence of Escherichia coli 0157: H7 in vegetables grown and sold in Lafia metropolis, Nigeria. World journal of Microbiology 1(3): 17-21.

16. Enabulele SA, Uraih N (2009) Entero hemorrhagic Escherichia coli 0157:H7 prevalence in meat and vegetables sold in Benin city, Nigeria. African Journal of Microbiology Research 3(5): 276-279.

17. Mora A, Usera MA, Blanco M, Blanco JE, Alonso MP, et al. (2000) Bacteriophage typing and virulence genes of verocytotoxigenic E. coli
(VTEC) 0157:H7 strains isolated in Spain. In: Duffy G, Garvey P, Coia J, Wasteson Y, Mc Dowell DA (Eds), Verocytotoxigenic E. coli in Europe, 3. Pathogenicity and virulence of verocytotoxigenic E. coli. Concerted Action CT98-3935. Teagasc, The National Food Centre, Dublin, IIreland, pp. 189.

18. Benard OA (2008) Prevalence of Escherichia coli 0157:H7 in water and meat and meat products and vegetables sold in the Eastern Cape Province of South Africa and its impact on the diarrhoeic conditions of HIV/AIDS patients. PhD thesis, Department of Microbiology, University of Fort Hare, South Africa. pp. 267-298.

19. Umoh JU (2001) An overview of possible critical control points of readyto-eat beef product of northern Nigeria. International conference on food and security, conference center Ibadan, Nigeria pp. 109-115.

20. Solomon EB, S Yaron, Matthews KR (2002) Transmission of Escherichia coli 0157:H7 from contaminated manure and irrigation water to lettuce plant tissue and its subsequent internalization. Appl Environ Microbiol 68: 397-400.

21. Brown CA, Harmon BG, Zhao T, Doyle MP (1997) Experimental Escherichia E. coli 0157:H7 Carriage in Calves. Applied Environmental Microbiology 63(1): 27-32.

22. Shisana D, Rehle T, Simbayi L, Parker L (2005) Rapid diagnosis of enterohaemorrhagic E. coli 0157: H7 in human stool samples. Journal of rapid Methods and Automation in Microbiology 10: 255-261.

23. Herman HM, Hall AJ, Gould LH (2015) Outbreak attributed to fresh leafy vegetables, United States, 1973-2012. Epidemiology Infection 143(14): 3011-3021.

24. Centers for Disease Control and Prevention (1999) Outbreak of Escherichia coli 0157:H7 and Campylobacter among attendees of the Washington County Fair-New York,. MMWR Morb Mortal Wkly Rep 48(36): 803-805.

25. Schlundt J, Toyofuku H, Jansen J, Herbst SA (2004) Emerging foodborne Zoonoses. Rev Sci Tech 23(2): 513-533.

26. Chekabab SM, Veillette JP, Dozois CM, Marel J (2013) The ecological habitat and transmission of Escherichia coli 0157:H7. FEMS Microbiology letters 341(1): 1-12.

27. Jawetz ELN, Melnick JL, Adelberg EA (1989) Medical microbiology. Appleton and Lange, Micheal publications Carlifornia. pp. 202-220.

28. Ministry of Economic Development (1996) Kaduna State Statistical yearbook, Kaduna Nigeria Ministry of Economic Development, Statistics Division.

29. Scheutz F, Strockbine NA (2005) Genus I Escherichia. In: Brenner DJ, et al., (Eds) The Protebacteria Part B tETEChe Gammaproteobacteria. Springer Bergey's Manual of Systematic Bacteriology 2(Part B): 607623. 